\title{
Siostry Klemensy od Wniebowzięcia (Janiny Wójcik) wspomnienia z zesłania (1940-1946)
}

\author{
Sisters Klemensa of the Assumption (Janina Wójcik) \\ memories of exile (1940-1946)
}

\section{Summary}

Sister Klemensa of the Assumption, Janina Wójcik (1893-1982), was born in Nowy Sącz, to the family of Ignacy - a railwayman and Jadwiga née Zwierzyńska. She graduated from the Private Teachers' Seminary in Tarnów, gaining qualifications to teach manual labor in elementary schools. She entered the Congregation of the Sisters of the Immaculate Conception in 1917. She made her perpetual profession in 1925. Before the outbreak of World War II, she worked in the monasteries in Wirów, Szymanów, Jarosław, Słonim, Niżniów and Maciejów as an economist, refectory and vestress. After the outbreak of World War II, she was forced to leave the monastery in Maciejów. She stayed briefly in Lviv. In 1940, she was deported to the Mariinsky Autonomous Socialist Republic of the USSR. She worked in the canteen in Nowa Strojka, then in the hospital in Joszkar-Oła. In the 1970s, Sister Klemensa wrote down retrospective memoirs entitled "Memoirs from Russia of Sister Klemensa of the Assumption (Janina Wójcik). My memories of the last war (1939-1946)". They count 25 single-sided pages. They include the time of deportation, with particular emphasis on information about the work performed. Sister Klemensa returned to Poland, to Nowy Sącz in 1946.

Słowa kluczowe: s. Klemensa od Wniebowzięcia (Janina Wójcik), Zgromadzenie Sióstr Niepokalanego Poczęcia NMP, zesłanie, Nowa Strojka, Joszkar-Oła 
Key words: Sister Klemensa of the Assumption (Janina Wójcik), Congregation of the Sisters of the Immaculate Conception, exile, Nowa Strojka, Joszkar-Oła

Siostra Klemensa od Wniebowzięcia NMP, Janina Wójcik (18931982) była niepokalanką. Urodziła się w Nowym Sączu, w rodzinie Ignacego - kolejarza i Jadwigi ze Zwierzyńskich. Ukończyła szkołę powszechną, a potem wydziałową w Nowym Sączu. Naukę kontynuowała w Prywatnym Seminarium Nauczycielskim w Tarnowie (wydział żeński w Nowym Sączu), które ukończyła w 1914 r., zdobywając kwalifikacje do nauczania robót ręcznych w szkołach powszechnych. Wówczas też złożyła egzamin maturalny. Wstąpiła do Zgromadzenia Sióstr Niepokalanego Poczęcia NMP w Jazłowcu, założonego przez Matki Józefę Karską i Marcelinę Darowską w 1917 r. Profesję wieczystą złożyła w 1925 r. Przed wybuchem II wojny światowej pracowała w klasztorach Zgromadzenia w Wirowie, Szymanowie, Jarosławiu, Słonimie, Niżniowie i Maciejowie jako ekonomka, refektarka i westiarka².

${ }^{1}$ Za początek istnienia Zgromadzenie Sióstr Niepokalanego Poczęcia Najświętszej Marii Panny uważa się rok 1857 i czas rozpoczęcia życia wspólnotowego pod przewodnictwem Józefy Karskiej w rzymskim klasztorze Casa della Madonna na Via Paolina, na mocy dekretu Kongregacji dla Biskupów i Zakonów z 25 listopada 1857 r. Po śmierci s. Józefy Karskiej od Jezusa Ukrzyżowanego w 1860 r. dzieło kontynuowała druga przełożona generalna - Marcelina Darowska (s. Marcelina od Niepokalanego Poczęcia NMP). Dom generalny Zgromadzenia w 1863 r. przeniesiono do Jazłowca. W murach klasztoru powstała szkoła dla dziewcząt $\mathrm{z}$ internatem, potem szkoła elementarna dla miejscowych dzieci. W 1871 r. rząd austriacki wydał oficjalne zezwolenie na osiedlenie się Zgromadzenia w Archidiecezji Lwowskiej, równoznaczne z urzędową zgodą na prowadzenie działalności o charakterze edukacyjnym. W kolejnych latach powstały klasztory w Jarosławiu (1875), Niżniowie (1883), Nowym Sączu (1897), Słonimie (1908) i Szymanowie (1908). Zgromadzenie prowadziło poza wymienionymi seminaria nauczycielskie żeńskie, szkoły gospodarcze, kursy zawodowe dla dziewcząt, sierocińce i placówki przedszkolne. W „Testamencie” Matka Marcelina pisała: „W wychowaniu naszem uszanować mamy narodowość", mając na uwadze postulat szkoły narodowej, tj. konieczność kontynuowania tradycji, bazując na historii. Matka Marcelina Darowska opowiadała się za edukacyjnym równouprawnieniem dla dziewcząt i kobiet, rozumianym przez ich gruntowne przygotowanie, pozwalające na realizowanie zadań ważnych społecznie i umiejętności samodzielnego myślenia. W działaniach edukacyjno-wychowawczych ważne miejsce zajmował imperatyw pracy dla ojczyzny. Zob. S.M. A. Jarząbek, Życie, myśl i dzieło Matki Marceliny Darowskiej wspótzałożycielki Zgromadzenia Sióstr Niepokalanek, Warszawa 1990, passim; S.M. Anuncjata od Trójcy Świętej, O wychowaniu w oparciu o zasady Matki Marceliny Darowskiej, Jarosław 2010; S.M. Grażyna od Wszechpośrednictwa NMP, Wychowanie to dzieło miłości. System pedagogiczny bt. Marceliny Darowskiej, Szymanów 1997; J. Lusek, Istota wychowania w koncepcji błogosławionej Matki Marceliny Darowskiej, [w:] A. Dawid, J. Lusek (red.), Kobiety na Kresach Wschodnich na przełomie XIX i XX wieku, Warszawa-Bellerive-sur-Allier-Bytom-Opole 2016, s. 95-111.

2 Archiwum Zgromadzenia Sióstr Niepokalanego Poczęcia NMP w Szymanowie (dalej: AZSNP), sygn. C II 1, S.M. Klemensa od Wniebowzięcia NMP. Janina Wójcik. 
Moment wybuchu II wojny światowej był dla s. Klemensy punktem odniesienia dla przygotowania retrospektywnych wspomnień, spisywanych przez nią na polecenie przełożonych i ostatecznie ukończonych przez nią w latach $70 . \mathrm{XX} \mathrm{w}^{3}$ Nadała im tytuł „Wspomnienia z Rosji s. Klemensy od Wniebowzięcia (Janiny Wójcik). Moje wspomnienia z ostatniej wojny (1939-1946)". Zostały spisane na maszynie. Liczą 25 jednostronnie zadrukowanych kartek, oprawionych w grubą zieloną tekturę. Obejmują czas deportacji do Maryjskiej Autonomicznej Republiki Socjalistycznej ZSRS, ze szczególnym uwzględnieniem informacji poświęconych wykonywanej pracy. Wspomnienia mają charakter unikatowy, nigdy nie były publikowane. Pokazują los jednostki - kobiety i zakonnicy, borykającej się z jednej strony z trudnościami izolacji od Zgromadzenia, z drugiej zaś z niezwykle trudnymi warunkami zakwaterowania i pracy, jaką s. Klemensa wykonywała w stołówce w Nowej Strojce, a następnie w szpitalu w Joszkar-Ole. W tekście właściwym wspomnień dokonano wyłącznie drobnych zabiegów stylistycznych (zgodnych z obowiązującymi zasadami interpunkcji i ortografii), pozostawiając właściwości pióra s. Klemensy.

Pierwsze wspomnienie czasu wojny dotyczyło 1 września $1939 \mathrm{r}$. Wczesnym rankiem nad Maciejowem pojawiły się pierwsze niemieckie samoloty zwiastujące konflikt między Niemcami a Polską. Siostry wraz z uczennicami przeszły do schronu. W kolejnych godzinach do klasztoru zaczęli napływać pierwsi uciekinierzy, którzy przemieszczali się na Wschód. S. Klemensa wspominała:

Cały dzień schodził nam na wydawaniu posiłków. Niektórzy prosili o przytułek, więc zebrało się około 200 osób. Dom był dobrze zaopatrzony, więc dzięki Bogu mogłyśmy biedakom przyjść z pomocą. (...) Cały park zajęło wojsko polskie wracające $\mathrm{z}$ frontu, wygłodniałe i wyczerpane do ostatka. Mówili, że cały ten czas żywili się tylko surowymi burakami, które wyrywali z pól. Niemcy widocznie ich zauważyli, bo nadleciały samoloty tak nisko, że mało o dach nie zaczepili. Kule z karabinów maszynowych gradem posypały się na ogród, gdzie bawiły się wtedy dzieci uciekinierów i nasze dziewczynki ${ }^{4}$.

Po agresji ZSRS na Polskę część zabudowań należących do maciejowskiego klasztoru, m.in. kaplicę ss. niepokalanek i sypialnie dziewcząt, zajęli czerwonoarmiści. Czas zajmowały im gra w karty i kości, gra na instrumentach i śpiew. Niemal natychmiast po wyjeździe ów-

\footnotetext{
${ }^{3}$ AZSNP, sygn. F V K2, Wspomnienia z Rosji s. Klemensy od Wniebowzięcia (Janiny Wójcik) od 1939 do 1946 roku, kk. 25 (maszynopis).

${ }^{4}$ AZSNP, sygn. F V K2, k. 1.
} 
czesnej przełożonej - s. Zofii Ustjanowicz ${ }^{5}$ - z chorą s. Eufrozyną do szpitala w Kowlu, ss. niepokalanki zostały wyrzucone z zajmowanych pomieszczeń. Zadecydowano, z uwagi na niebezpieczną sytuację, że powinny wyjechać bądź do swoich domów rodzinnych, bądź próbować przedostać się do pozostałych klasztorów Zgromadzenia. Kilka sióstr pojechało do Lwowa. Nieliczne, które pozostały na miejscu, przeniosły się tymczasowo na probostwo, do sali udostępnionej przez miejscowego proboszcza, a następnie do domu państwa Moczarskich. Zmuszone zostały do zmiany ubrań na świeckie. Czerwonoarmiści odbierali im pakowane naprędce drobiazgi. S. Klemensa wspominała:

Żołnierze rewidowali każdy balot ${ }^{6}$. Wyrzucali dzbanki i miednice, które każda chciała zabrać. Siostry kucharki zabrały trochę produktów i w wielkim garnku świnię zabitą po kryjomu. Kazali zrzucić z wozu, siostry nie chciały. Sami zrzucili. Siostry postawiły z powrotem. Znowu zrzucili i kazali odnieść do kuchni. Siostry okrążyły dom i znowu wsadziły garnek na wóz. Konie ruszyły szybko. Na parę dni miałyśmy czym się pożywić, dzięki zapobiegliwości i odwadze sióstr kucharek7.

Przez Kowel s. Klemensa dotarła do Lwowa, gdzie została przyjęta przez państwa Żebrowskich, rodziców niepokalańskich wychowanek. Za pośrednictwem Matki Zenony Dobrowolskiej ${ }^{8}$, wówczas przełożonej

${ }^{5}$ Zob. szerzej: J. Lusek, Poświecenie nie jedno ma imię. Siostra Zofia od Serca Jezusowego (Matylda Ustjanowicz), „Biografistyka Pedagogiczna” 2019, r. 4, nr 1, s. 145-165.

${ }^{6}$ Balot - szczelnie zapakowana paczka, tu: bagaż.

7 AZSNP, sygn. F V K2, k. 2.

${ }^{8}$ Siostra Zenona od Zbawiciela, Ludwika Dobrowolska (1879-1956) - niepokalanka. Urodziła się w Issakowie nieopodal Tłumacza, w rodzinie Zenona - powstańca styczniowego i Michaliny z Łukasiewiczów, wychowanka niepokalańska, krewna abp Józefa Teodorowicza. Jej siostra Sławomira wstąpiła do dominikanek, wyjechała do Francji, a potem na misję na Trynidad. W 1890 r. Ludwika Dobrowolska rozpoczęła naukę w szkole niepokalańskiej w Niżniowie. Po jej ukończeniu pracowała jako nauczycielka prywatna w domach Czartoryskich, Cieńskich i Oskierków. Jej rodzice, na skutek kryzysu gospodarczego, przenieśli się z majątku do Lwowa. Prowadzili potem pensjonat „Zacisze”, w którym Ludwika zajmowała się księgowością i kierowała zaopatrzeniem. Do Zgromadzenia wstąpiła we wrześniu 1907 r., profesję wieczystą złożyła w 1915 r. Była wychowawczynią kilku pokoleń dziewcząt, a zarazem kilku pokoleń zakonnych, w Jazłowcu, Niżniowie i Nowym Sączu. Nauczała religii, historii, języka niemieckiego i matematyki. W latach $1928-1933$ była radną generalną. W 1933 r. została wybrana trzecią z kolei przełożoną generalną Zgromadzenia, funkcję tę pełniła w latach 19331953. Jej dziełem są tzw. domki misyjne na Kresach Wschodnich II Rzeczypospolitej (Ilia, Głębokie, Wiszniew, Hołoby i Wołożyn). Pracujące w nich niepokalanki prowadziły przedszkola, zajmowały się również katechizacją oraz działalnością oświatową i charytatywną. Wspierała dzieło tajnego nauczania w szkołach niepokalańskich, pomoc więźniom, partyzantom i dzieciom żydowskim w latach wojny. Potrafiła na nowo, w trudnych latach II wojny światowej (i powojnia), odczytać charyzmat Zgromadzenia. Imperatyw pracy apostolskiej zaowocował otwarciem nowych domów i placówek na 
generalnej Zgromadzenia, otrzymała pracę jako opiekunka-pielęgniarka przy Wandzie Misiurgiewiczowej, która złamała nogę. Ta stołowała się w pensjonacie „Zacisze”, należącym do rodziny Dobrowolskich, którym kierowała wówczas Maria Horośnicka, rodzona siostra Matki Zenony. Misiurgiewiczowa mieszkała wspólnie ze swoją siostrą Janiną Załęską, pracującą w „Ossolineum” - przy ul. Stryjeńskiej, w budynkach ZUS-u. S. Klemensa zajmowała się sprawunkami i utrzymywaniem porządku w mieszkaniu, wspominała charakter swojej pracy:

Cała moja usługa polegała na tym, żeby otworzyć drzwi służącej, która przynosiła obiad z „Zacisza” i rano, po mszy świętej, przynieść świeży chleb i bułki ${ }^{9}$.

W połowie czerwca 1940 r. mieszkanie przy Stryjeńskiej zrewidowali przedstawiciele NKWD. Poszukiwali państwa Antoniewiczów, którzy schronili się tymczasowo u Wandy Misiurgiewiczowej. Właścicielki nie było wówczas w domu, po zdjęciu gipsu wyszła na miasto z siostrą. S. Klemensa została spisana, uwagę NKWD-zistów zwrócił również brak paszportu. 28 czerwca została deportowana na Syberię, do Maryjskiej Autonomicznej Republiki Socjalistycznej ZSRS. Wspominała moment aresztowania, przewiezienia na stację kolejową i podróży wagonem towarowym:

Pytają o mnie i każą w pół godziny być gotową do drogi. Co się działo! Wanda udarowała tego oficera papierosami, winem, chciała go przekupić. Dwa razy ten biedak chodził do władz, żeby mnie uratować. Nic nie pomogło. $\mathrm{W}$ domu nie było nic, bo dopiero po mszy św. miałam załatwić sprawunki. Więc tylko spakowałam trochę rzeczy, pożegnałam panie i wyszłam. Zaprowadzili mnie do drugiego domu, pod numer 36, na drugie piętro, do młodej Żydóweczki, akademiczki. Ją także mieli zabrać. U niej czekałam do 12.00 .

terenie Generalnego Gubernatorstwa i Mazowsza (Żbików, Wrzosów, Skierniewice, Koszajcu, Rząśnie, Koźlu, Górkach Mironowskich, Skolimowie i Złakowie Kościelnym). Matka Zenona była postacią znaczącą nie tylko we własnej wspólnocie, ale także inicjatorką porozumienia międzyzakonnego, tak ważnego dla przetrwania życia zakonnego na ziemiach polskich, w okresie represji politycznych i antyreligijnych. Domy Zgromadzenia powstały po wojnie w Mgoszczu, Gośćcu, Szczecinku, Wałbrzychu, Kościerzynie i Murkowie. W latach 1953-1954 była przełożoną klasztoru przy ul. Idzikowskiego w Warszawie, w latach 1954-1956 asystentką generalną i mistrzynią postulatu w Szymanowie. Jako przełożona generalna zabiegała o rozpoczęcie procesów beatyfikacyjnych założycielek Zgromadzenia - Józefy Karskiej i Marceliny Darowskiej. AZSNP, sygn. C II 1, S.M. Zenona od Zbawiciela. Ludwika Dobrowolska; sygn. F VIII 3.10, Biogram opr. S. Germana Wesołowska (Szymanów, 2000 rok), S. Zenona od Zbawiciela - Ludwika Dobrowolska, k. 1-6; Wspomnienia o współpracy międzyzakonnej zgromadzeń zakonnych żeńskich w Polsce, opr. M. Adela, k. 1-3.

${ }_{9}$ AZSNP, sygn. F V K2, k. 3. 
O 12.00 zajechał samochód ciężarowy już załadowany ludźmi. Wsiadłyśmy obie z Żydóweczką i Władzią Szwed, służącą u Żyda bogatego. Wszyscy mieszkańcy kamienic ZUS-u wybiegli do nas z płaczem, przynieśli mi słoniny kawał, chleba bochenek, garnek do gotowania, co kto mógł, bo się dowiedzieli, że ja nic nie mam. Zawieziono nas na jakąś odległą stację. Zanim dojechaliśmy wszystko mi ukradli.

Wieczorem wprowadzili nas do towarowych wagonów. Oficer był dla mnie bardzo grzeczny, wziął mój balot, podał mi rękę i wprowadził do wagonu po pomoście. Wszyscy ludzie awanturowali się, przeklinali - ja jedna byłam spokojna, bo wiedziałam, że to Wola Boża i uwierzyłam, że Bóg mnie nie opuści. Żydóweczka zabrała czajnik i szła po wodę. Ja też z nią poszłam. Kiedyśmy wracały zastąpił nam drogę bolszewik $\mathrm{z}$ karabinem i nie chciał nas puścić do wagonu. Skorzystała z tego Żydóweczka i uciekła, prosząc tylko, żebym się zaopiekowała jej rzeczami i powiedziała, że mogę ich tymczasem używać. Wróciłam z czajnikiem. Baliśmy się wszyscy, żeby nas nie ukarali za ucieczkę Żydówki. Wieczorem, na drugi dzień, przyszły do mnie Nina [Janina Załęska] i pani [Maria] Horośnicka. Przyniosły mi ubranie i żywność. Straż brutalnie je odpychała i nie pozwoliła zbliżyć się do wagonu. $Z$ daleka tylko pożegnałyśmy się, a w nocy pociąg ruszył. To był wagon po węglu, więc $\mathrm{z}$ ruszeniem pociągu miał węglowy nas zasypał. Dostałam pierwszy raz ataku serca, a pani Daciowa, żona kasjera ze Lwowa, rzuciła się do drzwi i chciała wyskoczyć, ale ja w porę zatrzymali. W wagonie było 14 osób: Daciow z żoną i córką, Biedowicz - kurator z Dębowej Łąki, co skasował naszą szkołę, z żoną i córką trochę nienormalną, inż. Kompf z Katowic, Klapscholtz - fabrykant obuwia z żoną i synem, Katz - właściciel kina z Krakowa i jego brat adwokat, też z Krakowa, Władzia i ja. Zaraz rano zabrałyśmy się z Władzią do czyszczenia wagonu, następnie panowie urządzili sypialnię, parawan $\mathrm{z}$ firankami na toaletę i bidecik, także osłonięty kotarą. Co dzień była świeża woda do mycia, gotowania, picia i prania. $\mathrm{O}$ wodę i otwieranie drzwi była stała walka dwóch Katzów z bolszewikami, którzy pilnowali, żeby drzwi były stale zamknięte i żeby nikt z wagonu nie wychodził w czasie postoju. Drzwi stale były otwarte, a mężczyźni stale wychodzili po wodę, kradli węgiel i drewno dla potrzeb kuchni, zdobywane przeklinaniem biednego bolszewika, a raz nawet pomimo nastawionego karabinu silnym jego odepchnięciem ${ }^{10}$.

Na mocy porozumień z III Rzeszą pod okupacją sowiecką, tj. na terenach włączonych w skład Białoruskiej i Ukraińskiej Socjalistycznej Republiki Radzieckiej (dalej: SRR), znalazło się ok. 194 tys. km

${ }^{10}$ AZSNP, sygn. F V K2, k. 5-6. 
przedwojennego polskiego terytorium, z 12,5 mln mieszkańców ${ }^{11}$. Do najważniejszych zadań władz lokalnych należało zaprowadzenie na nim zmian w zakresie struktury społecznej mieszkańców, wykorzystując przemyślany system działań o charakterze represyjnym. Od września 1939 r. podejmowane działania realizowano przy wsparciu grup operacyjnych NKWD ZSRS (Ludowy Komisariat Spraw Wewnętrznych Związku Socjalistycznych Republik Sowieckich). Przygotowały listy proskrypcyjne z nazwiskami uznanych za element wywrotowy - antyradziecki i kontrrewolucyjny. Objęto nimi ponad 12 tys. osób. W kolejnych trzech latach aresztowano łącznie ponad 120 tys. osób $^{12}$. Najbardziej dotkliwym narzędziem represji stały się przymusowe, prowadzone na masową skalę wysiedlenia i deportacje. Do ich przeprowadzenia władze sowieckie przygotowywały się od grudnia 1939 r. Komitet Centralny Wszechzwiązkowej Komunistycznej Partii (bolszewików) oraz Rada Komisarzy Ludowych ZSRS podjęły decyzję o usunięciu z terenów okupowanych tzw. elementów niepewnych, m.in. Polaków. W grupie tej, w pierwszej kolejności, znaleźli się przedstawiciele inteligencji, ziemiaństwa, administracji, żołnierze, rolnicy i przedstawiciele wolnych zawodów. Władze sowieckie miały zamiar w ten sposób pozbyć się wszystkich, którzy mogli stawić opór wobec okupanta i planowanych zmian społeczno-politycznych zachodzących na tych terenach w czasie tzw. pierwszej okupacji sowieckiej, tj. w latach 1939-1941. Zgromadzenia ludowe Białoruskiej i Ukraińskiej SRR, po wprowadzeniu ustroju sowieckiego, przejęły majątki ziemski i zakładały przemysłowe pozostające w rękach deportowanych ${ }^{13}$. Sprzedawano je za bezcen, pozostałe przejmowały kołchozy, sowchozy oraz inne instytucje o charakterze handlowym i gospodarczym ${ }^{14}$.

W latach 1940-1941 przeprowadzono łącznie cztery fale deportacji. Ludowy Komisariat Przemysłu Leśnego ZSRS i NKWD zobligowano do określenia miejsca rozmieszczenia przesiedlanych, Ludowe Komisariaty Zdrowia, Handlu i Komunikacji miały zająć się ich trans-

11 Mały Rocznik Statystyczny Polski wrzesień 1939 - czerwiec 1941, Warszawa 1990, s. 4 i 9; M. Gnatowski, W radzieckich okowach. Studium o agresji 17 września 1939 roku i radzieckiej polityce $w$ regionie łomżyńskim $w$ latach 1939-1941, Łomża 1997, s. 202-205.

${ }^{12}$ S. Ciesielski, G. Hryciuk, A. Srebrakowski, Masowe deportacje ludności w Zwiqzku Radzieckim, Toruń 2002, s. 208.

${ }_{13}$ A. Głowacki, Sowieci wobec Polaków na ziemiach wschodnich II Rzeczypospolitej 1939-1941, Łódź 1997, s. 39-127; M. Gnatowski, op. cit., s. 68-87.

${ }^{14}$ S. Ciesielski, G. Hryciuk, A. Srebrakowski, op. cit., s. 213-218; A.F. Chackiewicz, Aresztowania i deportacje zachodnich obszarów Białorusi (1939-1941), [w:] W. Balcerek (red.), Polska-Białoruś 1918-1945, Warszawa 1994, s. 137-138. 
portem i opieką medyczną. Na mocy specjalnego rozkazu z 9 stycznia 1940 r. powołano centralną komisję nadzorującą zadanie masowej deportacji, której podlegali naczelnicy zarządów obwodowych NKWD, im zaś rejonowe zarządy NKWD. Sporządzano grafiki wysiedleń, a deportowanym zakładano karty ewidencyjne. Pozostawiano im niewiele czasu na spakowanie dobytku. Transporty (eszelony) składały się maksymalnie z 55 wagonów, w tym 49 wagonów towarowych przystosowanych do przewozu ludzi. Przeciętnie w każdym przebywało ok. 25-30 osób. Jeden transport liczył średnio 1,2-1,5 tys. osób. Pociągi eskortowali żołnierze z Wojsk Konwojowych NKWD. Raz dziennie przesiedleńcom przysługiwał gorący posiłek i 800 gramów chleba ${ }^{15}$.

Podczas pierwszej fali deportacji (9/10 lutego 1940 r.) zesłano około 141 tys. osób, wśród nich wojskowych, urzędników niższego i średniego szczebla, kolejarzy i leśników ${ }^{16}$. Wywiezionych, łącznie ponad 89 tys. ${ }^{17}$, umieszczono w Kazachskiej SRR, Baszkirskiej Autonomicznej SRR, Komijskiej SRR, Kraju Ałtajskiego i Krasnojarskiego oraz w kilkunastu obwodach Rosyjskiej Federacyjnej SRR. Otrzymali status „specjalnych przesiedleńców”18. Podczas drugiej fali deportacji (12/13 kwietnia 1940 r.) deportacji poddano rodziny więźniów i jeńców wojennych przebywających w więzieniach i obozach na Ukrainie Zachodniej i w Białorusi Zachodniej. Na listach umieszczono ok. 25 tys. rodzin, w tym 75-100 tys. osób. Rozlokowano ich na północy Kazachskiej SRR, w rejonach aktiubińskim, akmolińskim, kustanajskim, pawłodarskim, północno-kazachstańskim i semipałatyńskim ${ }^{19}$. Pracowali w kołchozach i sowchozach oraz w osiedlach, gdzie prowadzono przedsiębiorstwa o różnej specjalizacji przemysłowej, a także przy budowie trakcji kolejowych ${ }^{20}$. Większość z przesiedlonych stanowiły dzieci i kobiety. Ich status prawny różnił się od przesiedlonych wcześniej bieżeńców. $Z$ formalnego punktu widzenia zostali deportowani w trybie administracyjnym na okres 10 lat. Rozmieszczono ich wraz z ludnością miejscową, nie wolno im było samodzielnie się prze-

${ }^{15}$ S. Ciesielski, G. Hryciuk, A. Srebrakowski, op. cit., s. 213-218; A.F. Chackiewicz, op. cit., s. 137-138.

16 A.F. Chackiewicz, op. cit., s. 137-138.

17 Ibidem, s. 140; A. Gurjanow, Cztery deportacje, „Karta” 1994, nr 12, s. 115-125.

${ }^{18}$ S. Ciesielski, G. Hryciuk, A. Srebrakowski, op. cit., s. 219, 222-223.

${ }^{19}$ Katyń. Dokumenty zbrodni. T. 2. Zagłada, marzec-czerwiec 1940, opr. W. Materski, Warszawa 1998, s. 79-80.

${ }^{20}$ S. Ciesielski, G. Hryciuk, A. Srebrakowski, op. cit., s. 240-241; A. Gurjanow, op. cit., s. 123-134; Z. Werra, Działalność duszpasterska w 2. Korpusie Polskich Sił Zbrojnych na Zachodzie gen. Władystawa Andersa 1941-1947, Warszawa 2009, s. 33; K. Jasiewicz, Liczba deportowanych, „Karta” 2001, nr 32, s. 143-145. 
mieszczać ${ }^{21}$. S. Klemensa została deportowana podczas trzeciej fali, przeprowadzonej od maja do lipca 1940 r. W grupie zesłanych znaleźli się bieżeńcy, wśród nich ludność przemieszczająca się w obawie przed okupacją niemiecką na wschodnie rubieże II Rzeczypospolitej. Wywieziono wówczas 79 tys. osób. Do ostatniej fali deportacji doszło tuż przed wybuchem wielkiej wojny ojczyźnianej, od maja do czerwca 1941 r., w czasie tym zesłano kolejne 42 tys. osób ${ }^{22}$.

Część transportu, którym przewieziona została s. Klemensa, rozlokowano w Kazachstanie, część w Maryjskiej Autonomicznej Republice ZSRS. Trafiła do Nowej Strojki. Krajobraz zdominowany był przez bezkresne leśne kompleksy, złożone z drzew iglastych. Z uwagi na chore serce siostra źle znosiła warunki zesłania, a przede wszystkim pracy fizycznej przy korowaniu drzew. Praca w lesie odbywała się w systemie brygadowym i tak też była rozliczana. Tydzień roboczy wynosił sześć dni, nierzadko pracowano również w niedziele. Normy były prawie niemożliwe do wykonania, obliczone na maksymalną eksploatację pracowników. Polacy nie byli nieprzygotowani do tego typu zadań, co rzutowało na zarobki, a niekiedy i na przydziały żywności. Porcje były nieadekwatne, zbyt skromne do rodzaju przypisywanych zesłańcom zadań, co było powodem ogólnego wyczerpania wielu z nich. Baraki mieszkalne pełne były robactwa, rzadko je dezynfekowano. Wykonane były z okorowanych potężnych bali sosnowych, pokrytych deska$\mathrm{mi}$, uszczelnione z zewnątrz mchem. Nie były pokryte tynkiem, gliną czy wapnem. Wyposażano je w kilka okien, słabo chroniły przed zimnem. Zesłańców lokowano na prowizorycznych, zbitych z desek łóżkach lub na żelaznych pryczach $\mathrm{z}$ siennikami. W izbach znajdowały się dodatkowo stoły i ławy do siedzenia oraz piecyki (kozy). Pozbawione były bieżącej wody, co determinowało rozwój chorób, przede wszystkim układu pokarmowego. Toalety zastępowały prymitywne wychodki, nieraz sama deska $\mathrm{z}$ otworem umieszczonym nad głębokim dołem. Zimą w pomieszczeniach mieszkalnych wydzielano zazwyczaj kąt zasłonięty płachtą, z kubłem służącym za sanitariat. Nie sprzyjało to zdrowiu mieszkańców. Pośrodku osiedla znajdowała się zazwyczaj

${ }^{21}$ S. Ciesielski, G. Hryciuk, A. Srebrakowski, op. cit., s. 241; Z.S. Siemaszko, W sowieckim osaczeniu 1939-1943, Londyn 1991, s. 87; A. Głowacki, Deportacje obywateli polskich do Kazachstanu i ich osiedlenie w latach 1940-1941, [w:] S. Ciesielski, A. Kuczyński (red.), Polacy w Kazachstanie. Historia i wspótczesność, Wrocław 1996, s. 298-306; S. Ciesielski, Praca polskich zesłańców w Kazachstanie (1940-1945), [w:] S. Ciesielski, A. Kuczyński (red.), op. cit., s. 329-339; S. Ciesielski, Polacy w Kazachstanie 1940-1946. Zesłańcy lat wojny, Wrocław 1996, passim.

${ }^{22}$ A. Głowacki, Deportacje obywateli polskich..., op. cit., s. 306. 
bania, która pozwalała na utrzymanie higieny. Brakowało naczyń, wiader czy misek. Pranie odbywało się w pomieszczeniach mieszkalnych, przy wykorzystaniu ługu sporządzonego z popiołu drzewnego ${ }^{23}$. Rodzina Biedowiczów, do której s. Klemensa została dokwaterowana, wyrzuciła ją z zajmowanej wspólnie izby. S. Klemensa pisała:

Zajechaliśmy do Kazachstanu przez tunel na Uralu, jechaliśmy nim pó1 godziny. Za Uralem wyrzucono parę osób i pociąg zawrócił. Po drodze też zostawiali po kilka osób. Bardzo prosiłam Matkę Najświętszą, żeby nas umieściła w najlepszym miejscu. Zawieziono nas do Maryjskiej Republiki i wysadzono w Nowej Strojce, w lesie. Stanęliśmy tam 19 lipca. Znajdowało się tam parę baraków, gospoda, dom enkawudzistów, dom, w którym mieszkała kucharka Nadia i cztery baraki dla nas. Przy wysiadaniu zapytałam jednego z naszych „opiekunów”, enkawudzistę, czy będą dobrzy dla nas? Odpowiedział: my tak, ale strzeżcie się waszych polskich renegatów, bo oni gorsi od czortów. Był już wieczór. Ułożyliśmy się pokotem, gdzie kto mógł, na gołej podłodze. W nocy zrobił się ruch niezwykły. Ludzie przewracali się, wstawali, drapali, przeklinali. Nikt prawie nie spał do rana, my także z Władzią. Okazało się, że tysiące wygłodniałych pluskiew rzuciło się na nas. Rano wszyscy, a najwięcej Żydów, udali się do naczalstwa ze skargą. Urządzili dezynfekcję. Rozdali nam łóźka i materace, pościel każdy miał ze sobą. Dostaliśmy także skórzane rękawice i wyplatane z kory łapcie na nogi, bo trzeba było $\mathrm{w}$ wodzie stać przy korowaniu drzew, a także narzędzia do ściągania kory. Przydzielili też każdej rodzinie jeden pokój w baraku. Nam z Władzią dostał się pokój z Biedowiczami. Wszyscy musieli iść do pracy. Biedowiczowa zaraz się zwolniła, że jest chora. $\mathrm{W}$ domu też nic nie robiła, tak jak i jej córka. Władzię wykorzystywali jako służącą. Została ona hojnie udarowana przez tego Żyda, u którego służyła, miała co sprzedawać. Zapasów też miała dość i była prawdziwą moją opiekunką i żywicielką. Była młoda i bardzo ładna. Pochodziła z Bochni. Tam zostawiła synka u rodziców, z mężem się rozwiodła. Bardzo była dobra, uczynna, opiekowała się mną jak matka. Pomagała mi w pracy w lesie, póki była ze mną. Była pobożna. Podobała się bolszewikom i zawsze dostawała, co chciała. Po paru tygodniach rozdzielili nas z Władzią. Ona dostała miejsce przy kolei, bo była silna i zdrowa. Ja w dalszym ciągu pracowałam w lesie przy ściąganiu kory z drzew i układaniu dwumetrowych bali do przesuszenia. Po wyjeździe Władzi Biedowiczowa myślała, że ja będę jej służącą, ale się zawiodła, bo wracałam z lasu bardzo zmęczona i wyczerpana i chciałam potem trochę odpocząć. Zaczęła mi dokuczać półsłówkami, aż razu pewnego zastałam moje rzeczy wyrzu-

${ }^{23}$ A. Pankiewicz, Sytuacja polskich zesłańców na Syberii w latach II wojny światowej, „Zesłaniec” 2016, nr 66, s. 67. 
cone na korytarz i drzwi do pokoju zamknięte. Poradziły mi sąsiadki, żebym poszła do państwa Bieńkowskich i powiedziała, co zaszło. Pani Bieńkowska ma dobre stosunki z enkawudzistami, ona pomoże. Tak też zrobiłam ${ }^{24}$.

Nowi współmieszkańcy, państwo Bieńkowscy, oraz nowe zadanie - praca w miejscowej stołówce - przyniosły s. Klemensie nieco wytchnienia. Praca była nadal ciężka, wymagała siły fizycznej potrzebnej do noszenia wiader z wodą, skoblowania podłogi czy garnków. Pozostawała na stołówce po 18 godzin dziennie. Stołówki funkcjonowały we wszystkich osiedlach, kołchozach i sowchozach. Mogły z nich korzystać osoby pracujące i członkowie ich rodzin. Posiłki były zazwyczaj dwudaniowe, jednak większość zesłańców mogła sobie pozwolić najczęściej na kupno zupy, co zdeterminowane było również liczbą osób w rodzinie. $\mathrm{Z}$ braku pieniędzy nie zawsze można było wykupić przysługujące porcje i niejednokrotnie odwiedzano stołówki raz na kilka dni. Dla większości była jedyną szansą na zjedzenie ciepłego posiłku w ciągu dnia. Podawano m.in. uchę - zupę rybną, szczi - kapuśniak z zielonych kiszonych liści kapusty, krupnik na kaszy owsianej bez ziemniaków, barszcz, zupę z łapszą (makaronem z żytniej mąki) czy rosolnik na kwasie z kiszonych ogórków. Cena porcji wahała się od 30-40 kopiejek do 2 rubli $^{25}$. Warunki atmosferyczne, przede wszystkim niezwykle mroźne zimy, były trudne do przetrwania. Istotnym problemem z tym związanym był naturalnie brak odpowiedniego ubrania. Deportacje odbywały się w różnych porach roku, ale i w rozmaitych okolicznościach. Podstawę ubioru zesłańców stanowiły głównie elementy garderoby przywiezione z kraju, tj. buty, płaszcze, bluzki, bielizna, swetry, spodnie, spódnice, kożuchy itp. Kolejnym problemem, $\mathrm{z}$ jakim się borykali, była odzież niezbędna do pracy na powietrzu ${ }^{26}$. $\mathrm{Z}$ czasem również i relacje między współmieszkańcami pogorszyły się, co nie pozostawało bez wpływu na sytuację s. Klemensy. Zagrożeniem dla kobiet byli również autochtoni, mężczyźni. Wspominała:

Państwo Bieńkowscy ofiarowali mi miejsce w mieszkaniu, a pani Bieńkowska zajęła się mną, ponieważ potrzebna była pomoc do stołówki. Postarała się, żeby mnie tam umieścić. Szybkimi krokami zbliżała się zima, mnie siły opuszczały z powodu ciężkiej pracy, coraz trudniej szła

${ }^{24}$ AZSNP, sygn. F V K2, k. 6-7.

${ }^{25}$ S. Ciesielski, G. Hryciuk, Warunki egzystencji, [w:] S. Ciesielski (red.), Życie codzienne polskich zesłańców w ZSRR w latach 1940-1946, Wrocław 1997, s. 82-83; A. Pankiewicz, op. cit., s. 63.

${ }^{26}$ S. Ciesielski, G. Hryciuk, op. cit., s. 112-114. 
mi robota. Jeden enkawudzista zaczął mnie obserwować na prośbę pani Bieńkowskiej, żeby mnie umieścić w stołówce. Raz jeden mi powiedział: grażdanka, ja na was patrzę i widzę, że wy pracowita, ale widzę, że wam robota nie idzie. Powiedziałam, że już nie mam sił. 1 września wołają mnie na milicję i każą iść pracować na stołówkę. Pytali, co tam będę chciała robić: być kelnerką, kucharką czy pomywaczką? Wybrałam to ostatnie, bo mnie ostrzegano, że każde odpowiedzialniejsze zajęcie grozi tiurmą, czyli aresztem. Trzeba było już o czwartej godzinie być na miejscu, żeby nanieść drzewa, rozpalić pod kotłem, umyć kuchnię i przygotować naczynia, bo już o szóstej naczalstwo przychodziło na śniadanie. Kuchnię trzeba co dzień było skoblować. Nie wolno było szorować szczotką, tylko umyślnie do tego zrobionym nożem zdzierać brud. Nie wolno było tego robić klęcząc, tylko na stojąco. To było dla mnie strasznie męczące. Musiałam dziennie wstawać o wpół do czwartej, bo nie wolno się było spóźnić. Poczciwa Nadia paliła za mnie pod kotłem, bo ja nie umiałam.

W nocy prawie nie spałam, bo pan Bieńkowski długo opowiadał o swoich przygodach, a mieszkaliśmy w jednym dużym pokoju. Przy drzwiach było łóżko starej pani Czajkowskiej-Bieńkowskiej, pochodzili z Ukrainy. Piękna staruszka z pańskimi nawyczkami. Co dzień przed spaniem musiała sobie kręcić maszynkami papiloty. Nie znosiła swojej synowej, która była aktorką w teatrze warszawskim. Musiałam wysłuchiwać skargi i żale przeciwko niej. Młoda pani Bieńkowska odbiła męża Szurze Matwiejewnej, żonie milicjanta, która pracowała ze mną w stołówce. Pani Bieńkowska przychodziła do domu późno w nocy i potem dopiero zaczynały się straszne rzeczy. Moje łóżko stało na środku pokoju. Z jednej strony było łóżko pana, z drugiej jego żony i córeczki. Mąż wybiegał z laską i przekleństwami i bił ją, ile miał sił. Raz nawet rzucił się na nią z siekierą, ale zdołała uciec.

Po takiej nocy musiałam na wpół przytomna wstawać o wpół do czwartej i iść do ciężkiej pracy. Oprócz naniesienia wody na cały dzień musiałam wynieść 40 wiader wody, a po południu naciągnąć do beczki 40 wiader. Ciągnęło się spuszczając wiadro do wody. Rano 40 wiader nosiła jedna z pomocnic, z pomocą drugiej. Ja musiałam nosić sama. Ale i za tę prace byłam wdzięczna Bogu, że nie potrzebowałam pracować w lesie, ale pod dachem i w cieple. Do stołówki przychodziło 600 osób. Miałam z początku 100 talerzy. Nie potrzebowałam się spieszyć z myciem. Potem było ich coraz mniej, bo Żydzi zabierali je z sobą do domów, wreszcie zostało mi ich dziesięć. Musiałam się bardzo zwijać przy myciu, żeby nikt nie czekał. Przed każdym posiłkiem pili wódkę, więc przy wielkim pośpiechu zdążyłam w porę przygotować talerze. Dopiero kiedy ostatni wyszedł ze stołówki wolno nam było zjeść śniadanie. Kiedy władza zobaczyła, że porządnie pracuję, to przyjęli do 
stołówki jeszcze dwie Żydówki - Hadasę na kelnerkę i Irmę na pomoc dla kucharki. Nie odróżniali Żydów od Polaków, wszyscy byli dla nich Polakami. Na śniadanie dali nam zupę. Zaczęłyśmy płakać, że nie jesteśmy przyzwyczajone, żeby rano jeść zupę. Dobry Iwan Krasielnikow zarządzający stołówką dawał nam mleko i chleb z masłem. Po śniadaniu i zmywaniu naczyń siadałam do obierania kartofli, wynosiłam wodę, nosiłam drzewo i znowu był obiad. Myłam naczynia, kotły były tak duże, że musiałam wchodzić do środka, żeby je umyć. Nie wolno było inaczej, jak tylko skoblować nożem.

Obserwowałyśmy kulturę naczalstwa, które jedząc rozpychało się rękoma przy stole. Zamiast widelcem jedli nożem. Nie wstawali wcześniej od stołu, aż im się nie odbiło, jak mówiła Irma. Po opróżnieniu stołówki i wymyciu naczyń zasiadałyśmy do obiadu. Potem musiałam nanosić 40 wiader i drzewa na kolację, obierać kartofle. I tak nadchodziła pora kolacji.

Raz był straszny mróz - ręce mi przymarzły do żelaza. Poszłam ciągnąć wodę i przymarzłam do studni. Nie mogłam się ruszyć. Iwan z dziewczętami wyszedł do okna. Wszyscy się cieszyli i śmiali z mojego nieszczęścia. Krzyknęłam na Iwana, żeby mnie odrąbał, bo się nie mogę ruszyć. Musiałam pracować do ósmej, czasem do dziewiątej wieczorem, przychodzili na piwo albo wódkę. Doki nie opuścili stołówki nie mogłam zejść ze stanowiska.

Ponieważ w stołówce rozmnożyły się karaluchy Iwan kazał przyjść w jedną bardzo mroźną niedzielę, pootwierał drzwi i okna, żeby karaluchy wymrozić. Miałam cienkie, letnie buciki i tak strasznie zmarzły mi nogi i ręce, że płakałam na cały głos. Poczciwy Iwan zaraz na drugi dzień kupił mi śliczne, lekkie walonki, tak ciepłe, że pomimo 50 stopniowego mrozu nie zmarzłam ani razu. Służyły mi przez całe sześć lat mojego pobytu w Rosji. Przyjechałam w nich do Polski i zostawiłam razem z płaszczem na stacji u kolejarza w Tarnowie.

Pewnej nocy śnieg spadł tak obficie, że pokrył na dwa metry wysokości rowy. Wyszłam do pracy około czwartej rano - ciemno. Nie widać było drogi, która prowadziła nad bardzo głębokim rowem. Boże, jak ja się dostanę do stołówki? Zaczęłam się modlić do Matki Bożej, bo gdybym postawiła fałszywy krok, to znalazłabym się w rowie, zakopana w śniegu. Mróz wielki, kto by mnie znalazł w polu? Nagle przede mną zjawił się mały, czarny piesek i wciąż biegał. Szłam za nim i doszłam szczęśliwie do stołówki, wtedy zniknął. Oglądałam się, ale już go nie zobaczyłam więcej.

(...) Na wiosnę był pobór do wojska - szykowali się na Niemców i Iwan został wzięty. Odjeżdżał w nocy, przyszedł do mnie do okna pożegnać się. Prosił, żebym pocieszała jego żonę i córeczkę i pomodliła się za 
niego, żeby wrócił szczęśliwie. Na jego miejsce przyszedł Żyd - Henryk Rejcher. Nadia, kucharka, także wyjechała. Mąż ją rzucił, została z córeczką. Często płakała biedactwo. Była bardzo dobra, cicha i pracowita. Na jej miejsce kucharką została Irma - Żydówka z Katowic. Z Rosjanek została tylko Szura, z Polek ja i Józia - służąca pani inżynierowej Oborskiej oraz Żydówki - Irma, Hadasa i Blimka.

Zapomniałam o jeszcze jednej, bardzo wyraźnej, opiece Matki Najświętszej. Dostałam zawiadomienie, że z Polski dostałam 50 rubli i mam się stawić na pocztę po ich odbiór, do drugiej wsi. Trzeba było iść przez las. Na poczcie zobaczyłam dwóch Maryjców, którzy wlepiali we mnie oczy. Pieniędzy nie dostałam, bo już ktoś inny je zabrał. Puściłam się w powrotną drogę, a maryjscy za mną. Przyśpieszam kroku, ile mogę i odmawiam „Pod Twoją obronę”, błagając Matkę Boską o ratunek. Maryjcy już parę kroków tylko ode mnie, a lasu nie ubywa. Wtem wychodzi jakaś kobieta zza drzewa i zatrzymuje ich rozmową. Ile tchu biegnę do stołówki, a oni znów za mną pędzą. Stołówka już blisko, wpadam i opowiadam Iwanowi. Zwolnił mnie i kazał drugimi drzwiami pędzić do domu, żeby mnie nie zobaczyli, bo Maryjcy to dzicz okropna, nieczysta. To rasa fińska, blondyni, trochę skośne oczy, nos spłaszczony. Bolszewicy chwalili się, że dopiero po zajęciu Maryjskiej Republiki zaczęli Maryjców zaznajamiać z kulturą. Odsunęli ich od urzędów i po prostu ten naród żyje w nędzy, jak zresztą i inne podbite narody. Sami też Rosjanie, z wyjątkiem komunistów, żyją bardzo biednie. W sklepach pustki, nic dostać nie można, z wyjątkiem 1 Maja i 7 Października, tj. w rocznicę rewolucji ${ }^{27}$.

Wybuch wielkiej wojny sowiecko-niemieckiej w czerwcu 1941 r. wniósł istotne zmiany na scenie geopolitycznej Europy. 12 lipca 1941 r. w Moskwie podpisana została deklaracja między ZSRS i Wielką Brytanią odnośnie do wzajemnej pomocy w toczącej się wojnie i zawiązania koalicji antyhitlerowskiej przeciwko III Rzeszy. Kilkanaście dni później, 30 lipca, w Londynie podpisano układ między Rzecząpospolitą Polską na uchodźctwie a ZSRS, w którym druga strona uznała traktaty niemiecko-radzieckie, a przede wszystkim niekorzystne dla Polski zmiany terytorialne za nieważne. Przywrócone zostały obustronne stosunki dyplomatyczne. Co jednak najważniejsze, rząd ZSRS wyraził zgodę na utworzenie, na terytorium swojego państwa, armii polskiej, która miała zostać oddana pod dowództwo wybranego przez rząd Rzeczypospolitej Polskiej na uchodźctwie, w porozumieniu z rządem ZSRS, dowódcy i podlegać Naczelnemu Wojskowemu Dowództwu ZSRS. Sygnatariuszami układu byli ze strony polskiej gen.

${ }^{27}$ AZSNP, sygn. F V K2, k. 7-10. 
Władysław Sikorski, ze strony sowieckiej Iwan Majski. Tego samego dnia podpisano także specjalny protokół, w którym w ślad za przywróceniem stosunków dyplomatycznych zobowiązano się do udzielenia amnestii obywatelom polskim, deportowanym, a potem osadzonym i przetrzymywanym na terytorium ZSRS ${ }^{28}$. Dekretowi amnestyjnemu podlegali ci, którzy przybyli do ZSRS przed 1 września $1939 \mathrm{r}$. (posiadający i nieposiadający paszportów), jeńcy wojenni z kampanii wrześniowej 1939 r., przybyli do ZSRS po 1 września 1939 r., aresztowani i wywiezieni do ZSRS do więzień i obozów pracy w pierwszych miesiącach wojny, aresztowani po 1 listopada 1939 r. na terenach okupowanych przez wojska sowieckie, aresztowani i wywiezieni do ZSRS do więzień i obozów pracy ${ }^{29}$, osoby deportowane z Zachodniej Ukrainy i Zachodniej Białorusi z czterech fal, wysiedleni między 1940 i 1941 r., uchodźcy z okupacji niemieckiej legitymujący się paszportami polskimi, niemieckimi i sowieckimi, robotnicy zwerbowani do ZSRS z paszportami sowieckimi, zmobilizowani do Armii Czerwonej w 1940 i 1941 r., bez dokumentów polskich oddanych podczas poboru, obywatele polscy deportowani z Wileńszczyzny, wreszcie ci, którzy w ZSRS przebywali w celach turystycznych, zdrowotnych ${ }^{30}$. Na mocy przepisów amnestyjnych z obowiązku świadczenia pracy przymusowej mieli zostać zwolnieni wszyscy obywatele polscy. Otrzymywali oni ważne na okres trzech miesięcy zaświadczenia amnestyjne. $\mathrm{Na}$ ich podstawie ambasada polska wystawiała paszporty. Działania te były celowo i skutecznie utrudniane przez stronę sowiecką ${ }^{31}$. Był to również moment przełomowy dla s. Klemensy. Za radą znajomych wyjechała do stolicy Maryjskiej Autonomicznej Republiki ZSRS, gdzie podjęła pracę w miejskim szpitalu. Narracja dotycząca lat 1941-1946 stanowi zdecydowanie najciekawszą część wspomnień s. Klemensy, mając również na uwadze unikatowość fragmentu poświęconego jej pracy jako salowej w Joszkar-Ole. Kwaterowała wówczas u Olgi Mikołajczykówny-Abaszynowej, następnie u państwa Koppesów. W tym czasie s. Klemensa pracowała na oddziałach zakaźnym, chirurgicz-

${ }^{28}$ Zob. J. Ślusarczyk, Układ polsko-radziecki z 30.7.1941 r., „Wojskowy Przegląd Historyczny" 1980, z. 3, s. 5-24; E. Duraczyński (red.), Układ Sikorski-Majski. Wybór dokumentów, Warszawa 1990.

${ }^{29}$ Zob. szerzej: R. Buczek, Działalność opiekuńcza ambasady RP w ZSRR w latach 1941-1943, „Zeszyty Historyczne” 1974, z. 29, s. 42-115.

30 P. Żaroń, Ludność polska w gtębi ZSRR w latach 1939-1941, [w:] A. Marszałek (red.), Położenie ludności polskiej na terytorium ZSRR $i$ wschodnich ziemiach II Rzeczpospolitej w czasie II wojny światowej, Torun 1990, s. 58.

${ }_{31}$ B. Szubtarska, Ambasada polska w ZSRR, Warszawa 2005, s. 82-83; O. Watowa, Paszportyzacja, „Zeszyty Historyczne” 1972, z. 21, s. 148-169. 
nym, wenerycznym, diagnostycznym i w wydzielonej części szpitala dla wojska. Wspominała:

Nadszedł dzień 1 września i zwolnienie nas spod „opieki” milicji. Mogłyśmy jechać, dokąd chcemy, tylko nie do Polski, i pracować po swojej specjalności. Co zrobić z sobą? Wyjeżdżać, ale dokąd, czy lepiej zostać samej w lesie? Ponieważ Rajcher był moim przełożonym na stołówce powiedziałam Jezusowi: jak on mi doradzi, to będę uważała to za Jego wolę. Zapytałam, co mam robić. Poradził mi jechać do JoszkarOły, stołecznego miasta Maryjskiej Republiki. Pojechałam. Na stacji w Joszkar-Ole spotkałam panią Oborską z krewnymi. Co robić i gdzie się obrócić? Przyłączyłam się do nich, oni też nie wiedzieli co robić, miasta nie znali. Ktoś nam doradził, żebyśmy się udali do jednego $\mathrm{z}$ domów niedaleko stacji. Tam miał być wolny pokój, w którym miał zamieszkać za parę tygodni ktoś $\mathrm{z}$ rodziny. $\mathrm{Z}$ wielką trudnością, ale przyjęli nas, z zastrzeżeniem, że na bardzo krótki czas. Po paru dniach pani Oborska z towarzyszkami znalazła mieszkanie. Mnie gospodarze zostawili, dopóki nie znajdę mieszkania. Takie było prawo, że kto nie ma posady, ten nie może dostać mieszkania. A kto nie miał mieszkania, ten nie dostawał pracy. Myślałam, że najlepiej byłoby się dostać do szpitala i zaczęłam robić starania. Na razie nie miałam mieszkania, powiedziałam dyrektorowi, że się staram o mieszkanie. Obiecał, że jak tylko będzie wolne miejsce, to zostanę przyjęta. Ufałam Bogu całym sercem i nadspodziewanie prędko moi tymczasowi gospodarze zapytali, czy nie chciałabym zamieszkać na wsi, bardzo blisko, u ich krewnej, Olgi Mikołajczykówny-Abaszynowej, bo właśnie jej męża wzięli na wojnę, a ona została $\mathrm{z}$ dwojgiem małych dzieci. Podziękowałam Bogu i im i z kartką polecającą udałam się na poszukiwanie Olgi. Bardzo się ucieszyła, kobiecina młoda jeszcze i jak się okazało bardzo dobra i pobożna, bezinteresowna. Pytałam, ile mam płacić za mieszkanie ani słyszeć o tym nie chciała, tak jak i jej krewni dzieliła się ze mną czym mogła i razem modliłyśmy się, żebym prędko dostała pracę, bo bała się, żebym nie miała nieprzyjemności. Po miesiącu dostałam wezwanie, żebym się stawiła do szpitala. Dyrektor przyjął mnie, ale tylko na salową, bo właśnie Moskwa i Petersburg (czyli Leningrad) uciekając schronił się w Maryjskiej Republice, ponieważ tu było bezpieczniej i zajęli wszystkie co lepsze miejsca. Jakże wdzięczna byłam Bogu, nie miałam pretensji. Dostałam się do szpitala, bo właśnie jedna salowa wyszła za mąż i nie chciała więcej pracować w szpitalu.

Zostałam przydzielona do małego szpitalika, dość odległego od głównego, do dzieci chorych na odrę. Ponieważ był to oddział zakaźny dostawałam podwójną rację chleba i prawie podwójną pensję. Dyżury nocne były tylko dwa razy w tygodniu, a po nocnym dyżurze następował jeden dzień wolny. Dzieci były bardzo milutkie, a pracy było niewiele, bo mat- 
ki same pilnowały swoich maleństw. Jedna była tylko niedogodność, po posiłki trzeba było chodzić do szpitala głównego. Najgorzej było temu, kto miał nocny dyżur. Ciemno było wszędzie, że okiem wykol, okna zasłonięte, światła na ulicach niezapalone. Obawiano się nalotów. Przypominam sobie jeden szczególnie przykry wieczór. Miałam nocny dyżur, deszcz lał jak z cebra. Ciemno, nie mogłam trafić do głównego szpitala. Tam mnóstwo domków, oddzielnie dla różnych chorób. Zupełnie jak drugie miasteczko. Znalazłam wreszcie kuchnię i dostałam pełne wiadro zupy dla dzieci. W mieście były trotuary z drzewa. Przy każdej bramie wjazdowej trotuar, każdy kończy się dość wysokim spadem, że można sobie rozbić głowę. Idę z zupą i z głębokości wołam do Pana o ratunek. Dochodzę z ledwością do bramy szpitalnej i staję bezradna. Zbliża się do mnie pijany żołnierz, bierze mnie pod rękę i odbiera wiadro z zapytaniem: gdzie idę i czy może mi towarzyszyć? Z lękiem, ale i z wielką wdzięcznością dla Boga, przystaję. Doszliśmy szczęśliwie do szpitala, oddał mi wiadro, podał rękę na pożegnanie i zapytał, czy może jutro do mnie przyjść. Prosił o adres, podałam mu naturalnie fałszywy. Śniadania i obiady jadłam w szpitalu, bo zostawało dużo po dzieciach, a kolacje w dni wychodne w domu u Olgi, albo w bardzo porządnej restauracji, gdzie spotkałam Marylkę Urbańską, właścicielkę Niżniowa. Bardzo żeśmy się ucieszyły. Odwiedzałam ją potem często. W lutym skończyła się epidemia odry i do szpitalika przywieźli chorych na tyfus plamisty i brzuszny. Jedna z salowych, która mieszkała razem ze mną u Olgi, zachorowała, bo się zaraziła od chorych. Olga tak się przeraziła, że jej do domu przyniosę zarazę, że kazała mi napisać podanie, żeby mnie zwolnili z tego oddziału, albo wypowie mi mieszkanie.

Podanie przyjęli, a ponieważ myśleli, że ja ze strachu się zwolniłam, to przenieśli mnie do szpitala wojskowego. Zaraz na początku doktór z tego oddziału, Walentyna Michajłowa, zaprowadziła mnie do ubikacji zalanej powyżej kostek kałem i najobrzydliwszymi brudami. Bez ścierki i bez wiadra kazała mi to wyczyścić, a potem zawołać ją i pokazać, jak to zrobiłam. W pierwszej chwili opanowały mnie taki wstręt i obrzydzenie, że wolałam zginąć z głodu, aniżeli to zrobić. W jednej chwili stanął mi przed oczyma duszy mej Pan Jezus, opluwany i obrzucany takimi samymi brudami, a ja nędzne stworzenie nie mogę się przełamać. Zdjęłam buciki, ubranie i zostałam tylko w samym szpitalnym fartuchu. Przeżegnałam się, boso weszłam w ten brud i rękoma zgarniałam do klozetu. Dość długo to trwało, ale wyczyściłam tak pięknie jak salon. Zawołałam doktórkę, która stanęła jak wryta, nie mogąc słowa wydusić. Na koniec powiedziała: Tylko Polaczka tak potrafiła zrobić! Od tej pory miała dla mnie wielkie uszanowanie. Nie pozwoliła mi zrobić krzywdy, a kiedy raz słyszała, że jedna z dziewcząt krzyknęła na mnie, zagroziła jej wydaleniem, o ile by się to powtórzyło. Po jakimś 
czasie przeniesiono mnie na oddział gruźliczy, także dla mężczyzn. Do moich obowiązków należało też chodzenie do laboratorium.

Niedługo tam pracowałam. W 1943 roku wybuchła straszna zaraza, ponad 30 chorób zakaźnych. Nawet dżuma się pokazała. Przenieśli mnie na oddział diagnostyki, gdzie rozpoznawali choroby i potem trzeba było chorych odprowadzać po odpowiednich oddziałach. Byłam na chirurgii ropnej, w wenerycznym, znowu w tyfusowym - tu były doktórki Żydówki, jedna z Moskwy, druga z Leningradu. Bardzo mnie lubiły. Nie pozwoliły nic robić, tylko doglądać chorych i donosić jedzenie. Zaraz zauważono ten wyjątek i doniesiono dyrektorowi. Za to kazano mi na dwa miesiące jechać do lasu i nosić bale do pociągu po drewnianym pomoście. Zaraz na wstępie włożono mi na ramiona dwumetrowy bal, pod którym upadłam na wpół żywa. Przybiegł dozorca przestraszony, pytając co się stało. Powiedziałam, że mam wadę serca i nie mogę dźwigać ciężarów. Kazał mi natychmiast wracać do szpitala. Nie wiedziałam, że powinnam była wziąć od niego zaświadczenie, że sam kazał mi odejść. Kiedy zgłosiłam się w szpitalu i powiedziałam wszystko zapytali mnie, gdzie mam kartkę od dozorcy. Dlatego, że nie miałam zaświadczenia orzekli, że sama uciekłam kazali mi iść do kołchozu i plewić hektar marchwi (w sierpniu!). Dwa tygodnie plewiłam pole marchwi i wyplewiłam dokumentnie, tak, że z marchwi sterczały tylko białe nitki, bo któż plewi marchew w sierpniu? Przyjechał dyrektor z zarządcą szpitala i znów byli zaskoczeni moją pracowitością. Znów usłyszałam, że tylko Polaczka tak się umie poświęcić tylko szkoda, że tak późno się do tego zabrali.

Pewnego dnia zjawiła się w szpitalu jakaś Rosjanka poszukująca Polki, która tu pracuje. Dano mi znać. Okazało się, że to była Polka, która już była przyjęta do ss. dominikanek w Krakowie, a ponieważ pracowała w szpitaliku rosyjskim jako dyrektorka, to musiała z nimi uciekać do Rosji. Tam poznała buchaltera, Rosjanina, któremu żona zwariowała i on został z dwojgiem małych dzieci. Zakochał się w niej i ożenił, naturalnie bez ślubu kościelnego. Po jakimś czasie zostawił jej synów, a sam złączył się z jakąś Żydówką, która pracowała u niego w biurze. Starszy syn, inżynier budowlany, ożenił się. Wziął matkę do siebie. Miał dwoje dzieci i babuszka te dzieci wychowywała, bo żona jego pracowała także jako inżynier leśny. Ta Polka, babuszka, chciała koniecznie, żebym u nich zamieszkała i dopytywała o mój adres, chcąc mnie odwiedzić i zabrać od Olgi. Przyszła nazajutrz, ale Olga schowała mnie do łóżka i przykryła kapą, żebym była niewidoczna, a jej powiedziała, że wyszłam do miasta. Nie dala za wygraną i kiedy się nie spodziewałam zobaczyła mnie przez okno i już nie mogłam się wycofać. Tak mnie męczyła naleganiem, żebym się do niej przeniosła, że musiałam rozstać się z kochaną, dobrą Olgą i przeniosłam się do babuszki. 
Zanim jednak to się stało spotkała mnie przygoda. Pracowałam w szpitalu. W tym dniu straszny był wicher i śnieg obficie spadł. O ósmej wieczór wyszłam do domu i przecież nie zmyliłam drogi. Było ciemno, ale domy odbijały się w śniegu. Już zdawałoby się powinien był być dom Olgi, ale go nie widzę, zamiast tego wielką białą górę. Wdrapuję się na nią i na samym wierzchołku zapadam się coraz głębiej. Zaczynam się złościć, potem krzyczę o pomoc. Ludzie śpią, nikt mnie nie słyszy. Przyjdzie mi tu zginąć myślę, bo straszny mróz. Zaczynam się modlić ufnie i gorliwie, po prostu krzyczę do Boga o ratunek i na nowo próbuję się wydostać i o dziwo w tym samym miejscu, w którym przed chwilą zapadłam się głębiej uchwyciłam się rakami i podniosłam w górę, a następnie stoczyłam po pochyłości. Dom Olgi był tuż za tą górą śniegu, nawianą w ciągu dnia. Olga była zdziwiona późnym powrotem, musiałam jej wszystko opowiedzieć - gdyby nie oczywisty cud, byłabym zamarzła.

Drugim razem wracałam z pracy, a zawsze musiałam przechodzić przez szyny kolejowe. Nie było w tym miejscu rampy, ponieważ pociągi rzadko tędy przejeżdżały. Byłam prawie w połowie toru, kiedy słyszę krzyk: Grażdanka, grażdanka! Odwracam głowę i widzę - o zgrozo - głowę olbrzymiego potwora, lokomotywę pociągu, który już tuż tuż za mną nadjeżdża. Jakaś siła cofnęła mnie wstecz. Gdybym była straciła przytomność i poszła wprzód już by było po mnie. Ledwo zdążyłam się cofnąć, a pociąg przejechał. Tak cicho, że nie było prawie słychać. I znów dziękczynienie - „Magnificat” za ocalenie. Zamieszkałam u Genadzi Koppesowa. Mieszkanie znajdowało się w budynkach terenu leśnego, bardzo blisko stacji kolejowej. Składało się z dwóch pokoi i kuchni. W sąsiedztwie mieszkała sprzedawczyni chleba na kartki. Genadzi, przybrany syn babuszki, był na wojnie. Została tylko synowa, babuszka i dwoje dzieci. Spałam z dziećmi w jednym pokoju, babuszka z synową Wierą w drugim obok kuchni. Dobrze mi było u nich, tylko 10 minut drogi od szpitala, dogadzała mi babuszka ile tylko mogła, dzieliła się wszystkim, prała bieliznę, czepek i fartuszek biały, szpitalny miałam zawsze czyściusieńki, bo wyjątkowo pozwolili mi prać w domu. Wszyscy z zazdrością mówili, że chodzę jak doktór. Bieliznę miałam jedwabną od Niny Załęskiej i kiedy raz musiałyśmy się stawić do badania, to doktorki mówiły do siebie: Żadna z nas nie ma takiej bielizny i ubrania jak ta salowa Nina. Kiedy wróciłam do kraju s. Emanuela obdarowała moją bielizną świecką i sukienkami bratową dawnej s. Walerii, która w czasie wojny wszystko straciła.

Znowu zostałam przeniesiona na chirurgię do Aleksandry Włodzimirównej, bardzo ładnej, dobrej i eleganckiej doktórki. Dowiedziała się, że ładnie ceruję pończochy, więc poprosiła mnie, żeby jej naprawić ładne, jedwabne. Zgodziłam się. Zapytała o cenę, powiedziałam, że robię 
to z grzeczności. Ona się nie zgodziła i od czasu do czasu przesyłała mi $50 \mathrm{rubli}^{32}$.

S. Klemensa opisywała również własne, pogłębiające się problemy ze zdrowiem spowodowane przeciążeniem fizycznym organizmu w trakcie wykonywania obowiązków w szpitalu, a także wadą serca. Relacjonowała:

Raz kazano nam przenieść na noszach do rentgena chorego mężczyznę, bardzo otyłego. Ja niosłam z przodu, a dwie salowe były z tyłu. Pokłóciły się i rzuciły nosze $\mathrm{z}$ chorym na ziemię i tak mnie zarwały, że dostałam strasznych boleści. Chirurg po zbadaniu orzekł, że musi być operacja, bo dostałam ruptury. Nie radził zaraz. Powiedział, że jak wrócę do Polski, bo to niebezpieczne.

Ponieważ nie mogłam dźwigać ciężko, a na chirurgii było to nieuniknione, bo na salę operacyjną i z powrotem trzeba było chorych nosić, przeniesiono mnie do interny, gdzie pracowałam aż do powrotu do Polski. Doktorem tego oddziału była Chłopcowa, bardzo dobra, średniego wieku osoba, pobożna. Skończyła medycynę w Moskwie, była wszechstronnie wykształcona. Skromna i cicha, zdawałoby się, że do dwóch zliczyć nie umie. Dużo skorzystałam, tłumaczył mi każdą chorobę i w jaki sposób ją leczyć. Powierzała mi staranie o chorych mówiąc, że nie może liczyć na siostry szpitalne. Dzięki temu uratowałam życie dwóm kobietom, za co Chłopcowa była mi bardzo wdzięczna.

Opiekowała się także i moim zdrowiem i nie wiem, czy wróciłabym do Polski, bo tak byłam wyczerpana. Kilka razy zemdlałam, ostatni raz w domu. Wróciłam z pracy i zrobiło mi się słabo. Babuszka kazała mi się położyć. Spałam wtedy w kuchni, bo mój gospodarz jako kaleka wrócił z wojny. Odmroził nogi, odcięli mu palce do połowy stóp, tak że biedak chodził tylko na piętach. Babuszka spała z dziećmi w pokoiku. Poprosiłam, żebym mogła spać sama w kuchni. Poszłam, ale zaraz wróciłam do babuszki. Bałam się zostać sama. Ledwo jednak doszłam do pokoju straciłam przytomność. Podobno dwie godziny leżałam nieprzytomna, usta miałam czarne jak węgiel, twarz sino-bladą. Istny trup. Wiera wróciwszy z pracy pobiegła po pogotowie. Przyszli, popatrzyli, kiwnęli ręką i powiedzieli, że tu już nic nie pomoże. Dowiedziawszy się o tym Żydówki, które przyszły z interesem, przyniosły flaszkę octu i nacierały mnie nim dopóty, dopóki nie odzyskałam przytomności. Dawały amoniak do wąchania i po kropelce wina wpuszczały przez zaciśnięte zęby. Na drugi dzień poszłam do pracy. Dostałam zaraz zastrzyki z glukozy - jeden kosztował wówczas 70 rubli. Od tej pory na wiosnę i z jesieni dostawałam po 10 zastrzyków z glukozy ${ }^{33}$.

\footnotetext{
${ }^{32}$ AZSNP, sygn. F V K2, k. 11-15.

${ }^{33}$ Ibidem, k. 15-16.
} 
W innym miejscu dodawała:

Pogoda była nieraz bardzo zmienna. Raz był silny mróz rano, a po południu odwilż, że szło się jak po szkle. Musiałam zdjąć walonki i w samych pończochach iść do domu, prawie na czworakach. zaziębiłam się i dostałam gorączki i tak poszłam na klinikę prosić o zwolnienie z pracy. Przez trzy dni miałam się nie pokazywać. Raz zemdlałam przy okienku, czekając na kolejkę ${ }^{34}$.

Trudności związane z działaniami na froncie skutkowały brakiem żywności w niemal wszystkich republikach ZSRS. Pozyskiwanie żywności możliwe było na kilka sposobów, tj. przez obowiązek pracy (jak też i rodzaj świadczonych usług), za które otrzymywano wynagrodzenie, handel wymienny z miejscową ludnością czy też w ramach przydziału prowiantu, rozdawanego w placówkach opiekuńczych polskiej ambasady. Podstawowym produktem żywnościowym był chleb, produkt deficytowy. Chleb sprzedawano w lokalnych małych sklepach, tzw. łarkach, na kartki (o czym s. Klemensa wspomina w dalszej części wspomnień). Cena za kilogram wynosiła średnio 0,8-1 rubla. Pracującym przysługiwało 0,4-1 kg, niepracującym 200-500 g. Zesłańcom przydzielano ciemny chleb żytni, w cenie 0,9-1,1 rubla za kilogram. W niektórych osiedlach dostępny był czasami chleb biały, pszenny w cenie 1,9 rubla za kilogram. Chleb wypiekano w prostokątnych formach przypominających cegłę, stąd też nazywano go kirpiczem ${ }^{35}$. Celem zapobieżenia trudnej sytuacji imano się różnych rozwiązań. Jednym z nich było wydzielanie niewielkich areałów ziemi dla poszczególnych rodzin, które można było obsiewać. S. Klemensa wspominała:

W Maryjskiej Republice zapanował głód. Zbyt dużo ludzi zebrało się tu uciekając przed wojną. Pola nie miał kto i czym uprawiać, bo wszystkich ze wsi zabrano do wojska i traktory też. Obawiano się chłopskiej rewolucji. Dużo wsi przedtem próbowało się wyzwolić spod ciężkiego jarzma komunizmu. Nic jednak nie poradzili, zostali uśmierceni lub uwięzieni, a wsi spalone. Teraz wszyscy poszli na pierwszy ogień, na rzeź, tylko po to, żeby ciałami swoimi choć na chwilę powstrzymali wroga, żeby komuniści mogli się uzbroić z pomocą amerykańską, wciągnąć nieprzyjaciela w głąb Rosji i tam go zwalczyć mrozem i regularnym wojskiem. Głód zmusił dyrektora, żeby nam dał po kawałku ziemi

${ }^{34}$ Ibidem, k. 20.

${ }^{35}$ K. Kość, Żywi we wspomnieniach. Doświadczenia śmierci $w$ relacjach polskich zesłańców w ZSRR (w latach 1940-1946), Wrocław 2008, s. 65-67; 6 S. Ciesielski, G. Hryciuk, op. cit., s. 126; G. Kowalski, Warunki życia codziennego na zesłaniu, „Zesłaniec” 2008, nr 36, s. 28. 
w ogrodzie, żebyśmy mogli posadzić kartofle. Każdy z nas dostał kawałek równy 100 męskim krokom w kwadrat i po 4 kg kartofli. Zaczęłam kopać, ale ani rusz nie mogłam wbić łopaty w ziemię, dopiero jedna Polka, która miała chore dziecko w szpitalu pomogła mi i w jednej chwili skopała ziemię. W trzy miesiące po posadzeniu kartofli zebrałam ich $25 \mathrm{~kg}$, ślicznych i ogromnych. Wzięłam w worku na plecy, żeby zanieść do domu i razem z nimi stoczyłam się po schodach na ziemię. Zobaczył to dyrektor i pierwszy raz dostałam straszną burę. Kazał zanieść moje kartofle do domu, a mnie zawrócił do oddziału, kazał odpocząć i wziąć lekarstwo ${ }^{36}$.

S. Klemensa wspomina także o procederze związanym z pozyskiwaniem drewna na opał dla oddziału, w którym realizowało się obowiązek pracy. Spoczywał on na personelu pomocniczym, m.in. na salowych:

Zawsze $\mathrm{w}$ jesieni i na wiosnę sanitarki, które nie umiały pracować w lesie dla zaopatrzenia swojego oddziału w drzewo na zimę (doktórki najmowały je za siebie) musiały iść do kołchozu sadzić kartofle, a potem je zbierać. Dwa tygodnie sypiałam wtedy na ławie, tylko płaszcz podtykając pod głowę. Nie miałam co jeść, bo nie mogłam wykupić chleba. Dziewczęta, które tam pracowały, ze wsi, tak sobie bez skrupułów radziły, że jeden worek kartofli sadziły (bardzo daleko jeden od drugiego), a drugi brały dla siebie i piekły. Mnie też dawały. Czasem też dostałam trochę mleka. Po powrocie trzeba było znów zastępować te salowe, które szły do lasu' ${ }^{37}$.

S. Klemensa sporo uwagi poświęciła we wspomnieniach również relacjom międzyludzkim wśród miejscowej ludności, co dotyczyło pracowników szpitala, składu aptecznego, ale również pacjentów. Wzmiankowała także obecność na oddziałach zakamuflowanych przedstawicieli NKWD, którzy podburzali do podejmowania tematów politycznych i mieli za zadanie raportowanie o podejrzanych przypadkach i donosach:

W oddziale były cztery duże sale - dwie dla kobiet i dwie dla mężczyzn. Rano, a czasem po południu, po śniadaniu i zmyciu naczyń, a także sprawdzeniu, czy chorzy wszystko mają i czego im potrzeba i czy utrzymani są w czystości, szłam do apteki. Ten obowiązek piastowałam w każdym oddziale. Doktorki mówiły, że to, czego one nie dostaną, to ja zawsze przyniosę. Raz brakło jakiegoś lekarstwa, dostałam z apteki kartki z poleceniem do głównego składu, żeby mi wydano. Tak mnie lu-

\footnotetext{
${ }^{36}$ AZSNP, sygn. F V K2, k. 18-19.

37 Ibidem, k. 20.
} 
biły farmaceutki, że spod ziemi wyciągnęłyby potrzebne lekarstwa. Zawsze byłam im wdzięczna, z szacunkiem się do nich odnosiłam, chwaliłam suknie, ich wygląd. I to ich tak ujęło. Musiałam im też opowiadać o zwyczajach w Polsce.

Częste były w szpitalu wypadki otrucia, to też była dla nich zawsze sensacja, najczęściej chodziło o zawiedzioną miłość, a to znów z rozpaczy jakiś więzień. Leczono go, a potem znów miał iść do więzienia. Milicjant dzień i noc nie odstępował od jego łóżka. Prawie w każdym oddziale leżał chory „wtyczka” z NKWD.

Jeden taki wciąż mnie zaczepiał na tematy polityczne. Nie odzywałam się, udawałam, że nie słyszę. Aż raz mówi mi: Wasz Piłsudski to był dopiero głupi człowiek, zachciało mu się iść na Kijów i by całą Polskę stracił. Tego już nie mogłam darować i powiedziałam: Wyście byli mądrzejsi, boście cały rok karmili Niemców najlepszą pszenicą, żeby was teraz dobrze bili. Zamilknął, od tej pory miałam spokój.

Inny znów, żeby mi dokuczyć i zwrócić na siebie uwagę, zrobił okropny nieporządek koło swojego łóżka, napluł flegmą i kazał mi to sprzątać. Mówię u: Wstań i sprzątnij sam! A on pyta: Od czego ty jesteś? Sprzątaj zaraz! Odpowiedziałam: Jeżeli ktoś jest ciężko chory, to sprzątam. Ty chodzisz i możesz sam sprzątnąć. Zresztą żaden chory nie jest tak niekulturalny jak ty. Poszłam do doktórki. Kazała mu wstać i sprzątnąć, bo inaczej zaraz go wypisze ze szpitala. Przez zaciśnięte zęby powiedział mi: Gordyja Polaczka, to znaczy dumna Polka. Tak, powiedziałam, myślisz, że jestem jak wasze dziewczęta? Na drugi dzień rano patrzę, a łóżko czyściutko zasłane, koło łóżka wzorowy porządek. On pyta mnie: czy jestem kulturalny? O tak, teraz tak - odpowiedziałam. Był uszczęśliwiony. Odtąd sam utrzymywał porządek koło siebie ${ }^{38}$.

W innym miejscu dodawała:

W tym czasie przyjechała do babuszki jakaś pani z Moskwy i dała jej dużo kartek chlebowych, mnie także. Babuszka prosiła mnie, żebym sprzedawała chleb, który wykupywała na te kartki od Olgi, chorym w szpitalu. Za bochenek chorzy płacili po 40 rubli, a babuszkę kosztował tylko cztery ruble. Dość długo udawało mi się go sprzedawać, bo chorzy z wdzięcznością go kupowali, aż dowiedziało się o tym NKWD. Pewnego razu woła mnie dyrekcja szpitala i mówi: Nina Ignatiwena, was szpiegują, że sprzedajecie chleb. Nie róbcie tego więcej, bo was zamkną do więzienia. Podziękowałam za ostrzeżenie i obiecałam, że tego więcej robić nie będę. Babuszka musiała zrezygnować z zarobku. Na swoje kartki uskładałam z 4 tys. rubli ${ }^{39}$.

\footnotetext{
${ }^{38}$ Ibidem, k. 16-17.

39 Ibidem, k. 19.
} 
W 1946 r. pojawiła się możliwość powrotu do Polski, z której s. Klemensa po zasięgnięciu porad skorzystała. Miejsce w wagonach kierowanych do ojczyzny wymagało jednak znacznych nakładów finansowych, na które nie było jej stać. W zamian za okazanie troski o stan zdrowia nieznajomego, którym okazał się zamożny Żyd - dentysta Waldmann z Krakowa, s. Klemensa wróciła do klasztoru. Do czasu wydania oficjalnego zezwolenia przygotowywała się do otrzymania uprawnień pielęgniarskich, ponieważ zgodnie z obowiązującymi procedurami mogła wyjechać wyłącznie jako siła wykwalifikowana, towarzysząc inwalidzie. $W$ trakcie drogi doznała oparzenia podczas zapalania piecyka (kozy), który znajdował się w wagonie, którym podróżowała. Wspominała:

Przed samym wyjazdem Polacy znieśli dużo płaszczy do mieszkania babuszki. Wybrała dla mnie bardzo ładny czarny płaszcz, imitacja karakułów, takąż czapeczkę i mufkę. Bardzo mi się przydał na drogę.

Raz byłam na klinice, kiedy przyniesiono na noszach Żyda ze złamaną nogą i porzucono na korytarzu, a mróz był straszny. Nikt się nim nie zajął i byłby tak leżał nie wiadomo, dokąd, aż ja nie zrobiłam krzyku - bo tak trzeba było, żeby zwrócić uwagę, że jak można tak zostawić chorego na takim zimnie. Przybiegły siostry i zabrały go do doktora. Nie wiedziałam, kto to był i nie byłam ciekawą dowiedzieć się.

Po jakimś czasie dentysta z Krakowa - Waldmann prosi mnie przez córkę, żebym do nich przyszła, bo ma do mnie prośbę. Przyszłam, zapytał czy nie mogłabym z nimi jechać do Polski, bo on kupił sobie wagon i z wdzięczności, że się nim zajęłam na klinice chce mnie wziąć ze sobą. Podziękowałam serdecznie, ale nie dałam mu odpowiedzi dopiero po namyśle. Opowiedziałam wszystko babuszce. Ona też trochę się obawiała jakiegoś podstępu, więc poszłam do Daciowa, znajomego z pociągu do Nowej Strojki. Dowiedziałam się o śmieci jego żony, został sam z córką. Myślę, zrobię tak jak on mi doradzi. Taka będzie Wola Boża, a potem niech się dzieje, co chce. Rozważał za i przeciw, bo w tym wagonie mieli jechać sami Żydzi. Wreszcie zdecydował, żebym jechała, bo to być może jedyna okazja powrotu do Polski.

Odpowiedziałam Waldmannowi, że pojadę. Rozchodzi się tylko o to, czy mnie puszczą ze szpitala i czy w ogóle władze zgodzą się na wyjazd. Przedstawiłam sprawę Chłopcowej. Zdecydowała, że mogłabym pojechać tylko jako siostra szpitalna z chorym kaleką. Rozpoczęła starania. Przede wszystkim powinnam się była nauczyć robić zastrzyki, bo inne rzeczy potrafię. Nie chciałam w żaden sposób, bo bałam się kłuć chorego. Na oddziale leżała umierająca kobieta. Doktór Chłopcowa kazała mi jej zrobić zastrzyk uspokoiwszy mnie, że ona już nic nie 
czuje. Dość czasu upłynęło zanim się zdecydowali dać pozwolenie na wyjazd.

Nastąpiło pożegnanie wszystkich znajomych po kolei, potem chorych. Płakali, narzekali, kto im będzie służył tak jak ja. Przyszłam pożegnać dyrektora i zarządcę szpitala. Na pożegnanie odczytali mi wycinek z gazety wychwalający wszystkie moje zalety, bo nie słyszano nigdy, żeby Polka mogła się tak poświęcić i tak pracować dla ruskiego narodu. Podziękowanie było wzajemne. Z gospodarzami było wręcz rozczulające, z obietnicą wzajemnej korespondencji. Zostawiłam im 3 tys. rubli. Sobie zostawiłam tys., bo mnie ostrzegano, że na granicy resztę zabierają. Okazało się jednak, że mogłam była zabrać wszystko, bo wyjątkowo w naszym wagonie nie przeprowadzono rewizji, ale któż mógł to wiedzieć. Żydzi po drodze wymieniali ruble u jakichś mężczyzn, którzy chodzili po wagonach.

Do naszego przyczepiono wiele innych, też z Żydami i rodzinami polskimi. W jednym z nich jechała Janka Czerwińska z chorą matką, nasza uczennica jarosławska. Do pociągu odprowadziła mnie babuszka. W naszym wagonie byli sami Żydzi: Waldmann z żoną i córką, Fromer inżynier z żoną i matką staruszką, fabrykant z 16-letnim synem i żoną i ja. Sypialnie były piętrowe z jednej strony. Na piętrze spał Waldmann z rodziną, na parterze Żydówka - żona fabrykanta z synem, po drugiej stronie wagonu na piętrze fabrykant, ja, Fromer z żoną i matką. Na parterze były pakunki, pod spodem węgiel i drzewo z jednej i drugiej strony, a także różne produkty, których Żydzi moc zabrali z sobą. Kuchnia stała na środku wagonu. Ja miałam tylko trochę żywności, nie starczyłoby mi na całą drogę. W południe przynosili nam zupę, a wieczorem śledzie.

Wyjechaliśmy 17 marca, mróz był 40 stopniowy, Ja znów z gorączką przeszło 38 stopni, nie mogłam jednak prosić o pomoc lekarską, bo nie byliby mnie puścili. Zaraz na początku przyszli sprawdzać czystość. Kto miał wszy, tego odstawiali do domu. Dyżury rozłożone były dla wszystkich, kto miał dyżur nocny musiał rozpalać w piecu. Widziałam, że Żydzi polewali drzewo naftą i szybko rozpalali. Raz wypadł na mnie dyżur nocny. Wzięłam bańkę myśląc, że to nafta (bo zawsze w niej była) i oblałam drzewo, które się już trochę tliło. Nagle płomień buchnął na całą przestrzeń przed kuchnią. Benzyna, która wieczorem została nalana do bańki, zaczęła się palić w bańce. Waldmann już nie spał. Skoczył z chorą nogą i zaczął kocami gasić ogień. Płaszcz i sukienkę oblałam benzyną, stanęłam w płomieniu. Podeszłam do drzwi i modliłam się o cud, żeby nikt nie spalił się prócz mnie. Wtem zerwał się nagle ze snu ten 16-latek Żydek i otwiera drzwi, do nich trzeba było zawsze czterech dorosłych mężczyzn. Porywa palącą się, gorącą bańkę z benzyną i wyrzuca na śnieg. Benzyna rozlewa się i tworzy krąg ognia. To było w Tule. 
Na stacji mnóstwo wojska i ludzi. Za przewożenie materiałów palnych czekało więzienie. Myśmy wszyscy drżeli i czekali, że nas zaaresztują. Tymczasem nikt nie zauważył ognia ani z którego wagonu coś zostało wyrzucone. Kocami zaduszono pożar, nic się nie spaliło, tylko moja sukienka, czapeczka na głowie i rzęsy. Ran nie miałam, tylko trochę gorąca. Teraz czekałam, co mi zrobią Żydzi za to, że ich mało nie spaliłam i naraziłam na wielkie niebezpieczeństwo. Jedni po drugich przychodzili mi dziękować, że moja modlitwa ich uratowała. Waldmann dał mi medalik Matki Boskiej Częstochowskiej na złotym łańcuszku, Fromer krzyżyk z Jerozolimy, a panie ściskały mnie i całowały. Jakże dziękowałam Matce Najświętszej za ocalenie. Ponieważ byłam chora nie pozwolono mi nic robić. Całymi dniami czytałam książki, które mi pożyczali. Fromer zamęczał mnie swoim komunizmem. Chwaliłam niektóre dobre strony komunizmu, zastrzegłam, żeby się nie rzucali na kościół, na religię, na naród polski, który jest na wskroś religijny. Zaręczał, że komunizm do religii wcale nie będzie się mieszał. Dla żony, która była cichutka i anielsko dobra, cierpliwa, był nieznośny. Traktował ją jak swoją niewolnicę, która musiała być zawsze na jego usługi i kaprysy. Po południu przychodził zawsze jakiś ich znajomy i rozpoczynała się uczta. Ile oni mieli dobrych trunków i różnych rzeczy, owoce południowe, tafle czekolady, ciasta. Musiałam wszystko z nimi spożywać. Bardzo się gniewali, kiedy odmawiałam. O obiady była zawsze sprzeczka między nimi, bo każdy chciał mnie gościć. Wreszcie stanęło na tym, że co dzień inna rodzina będzie mnie karmić ${ }^{40}$.

Szczęśliwie dla s. Klemensy pociąg zmienił kurs z powodu wypadku innego pociągu na trasie. Wysiadła w Tarnowie, a następnie pojechała do klasztoru w Nowym Sączu. Spotkanie ze współsiostrami było dla niej niezwykłym przeżyciem. Pomimo trudów zesłania szybko wróciła do pracy, nie potrafiła odpoczywać. Relacjonowała:

Mieliśmy jechać do Polski przez Brześć, tymczasem dano znać, że pociąg, który tamtędy jechał przed nami akowcy wysadzili w powietrze. Musiano zawrócić na Medykę. Tam przeprowadzono rewizję po wszystkich wagonach. Dużo się obłowili. Przez nasz wagon przeszli. Mężczyźni, którzy mieli złoto zaszyte dyskretnie w ubraniu usiedli na uboczu. Kobiety zajęły naczelne miejsca. Obejrzano się za mężczyznami. Zapytali o paszporty. Zamienili pieniądze i odeszli. Znów dziękowali Żydzi, że moja modlitwa uratowała ich od rewizji. Bardzo pragnęłam wysiąść w Jarosławiu, ale nasz pociąg zatrzymał się dopiero w Tarnowie. Wysiadłam, znalazłam kolejarza i zapytałam, czy w Nowym Sączu są jeszcze ss. niepokalanki. Są - odpowiedział - nawet moja córka uczy się u sióstr. Zapytałam, kiedy odchodzi pociąg do Sącza. Odparł, że do-

${ }^{40}$ Ibidem, k. 22-24. 
piero o 7.00 rano i muszę przenocować w Tarnowie. Ofiarował mi swoje mieszkanie.

Pożegnanie z moimi dobrodziejami było serdeczne, dziękczynne. Nie chcieli mnie puścić w żaden sposób. Waldmann prosił, żebym z nim jechała do Krakowa. Fromer chciał mnie zabrać do Warszawy. Powiedziałam im, że muszę wracać do klasztoru. Rzeczy swoje przezornie umieściłam przedtem obok drzwi, wyrzuciłam je na ziemię i szybko uciekłam. Rano kolejarz zaniósł mi pakunki.

(...) Nareszcie znalazłam się w kaplicy. (...) S. Emanuela zabrała mnie przed ciekawym okiem dzieci i ukryła w zakonnym refektarzu. Po Officjum przyszły siostry - żadna mnie nie poznała. Zaraz przyniosły mój habit na powtórne obłóczyny. Potem była wieczerza, bardzo radosna i wesoła. S. Emanuela kazała mi dwa tygodnie odpoczywać. S. Aniela, z którą spałam, leczyła mnie z gwałtownego kaszlu kroplami terpentynowymi na cukrze. Kaszel ustał, ale terpentyna źle podziałała na serce. $\mathrm{Z}$ odpoczynku nie skorzystałam, bo jak zobaczyłam siostry wymizerowane, chore, wymęczone, brudy i nieporządki po bolszewikach, to od razu zabrałam się do roboty. Najpierw w ogrodzie pomagałam s. Alojzie przy truskawkach, a potem z s. Eufemią zabrałyśmy się do oczyszczania ścian z napisów bolszewickich i uporządkowania pokoi ${ }^{41}$.

S. Klemensa pracowała po powrocie do Polski i do Zgromadzenia jako pomocnica ekonomki, westiarka i refektarka w Nowym Sączu (1946-1947, 1949-1950, 1973-1982), asystentka intendentki we Wrzosowie (1947-1949), księgowa w Mgoszczu (1950-1955) oraz westiarka i pomocnica w kaplicy w Murkowie (1955-1973). Zmarła w Nowym Sączu w 1982 r. $^{42}$

\section{Bibliografia}

\section{Źródła archiwalne}

Archiwum Zgromadzenia Sióstr Niepokalanego Poczęcia NMP w Szymanowie:

sygn. C II 1, S.M. Klemensa od Wniebowzięcia NMP. Janina Wójcik, sygn. C II 1, S.M. Zenona od Zbawiciela. Ludwika Dobrowolska, sygn. F V K2, Wspomnienia z Rosji s. Klemensy od Wniebowzięcia (Janiny Wójcik) od 1939 do 1946 roku, kk. 25 (maszynopis), sygn. F VIII 3.10, Biogram opr. S. Germana Wesołowska (Szymanów, 2000 rok), S. Zenona od Zbawiciela - Ludwika Dobrowolska, k. 1-6,

${ }^{41}$ Ibidem, k. 24-25.

${ }^{42}$ AZSNP, sygn. C II 1, S.M. Klemensa od Wniebowzięcia NMP. Janina Wójcik. 
sygn. F VIII, Wspomnienia o współpracy międzyzakonnej zgromadzeń zakonnych żeńskich w Polsce, opr. M. Adela, k. 1-3.

\section{Opracowania}

S.M. Anuncjata od Trójcy Świętej, O wychowaniu w oparciu o zasady Matki Marceliny Darowskiej, Jarosław 2010.

Balcerek W. (red.), Polska-Białoruś 1918-1945, Warszawa 1994.

Buczek R., Działalność opiekuńcza ambasady RP w ZSRR w latach 1941-1943, „Zeszyty Historyczne” 1974, z. 29.

Ciesielski S., Polacy w Kazachstanie 1940-1946. Zesłańcy lat wojny, Wrocław 1996.

Ciesielski S., Kuczyński A. (red.), Polacy w Kazachstanie. Historia i wspótczesność, Wrocław 1996.

Ciesielski S. (red.), Życie codzienne polskich zesłańców $w$ ZSRR w latach 1940-1946, Wrocław 1997.

Ciesielski S., Hryciuk G., Srebrakowski A., Masowe deportacje ludności w Zwiazku Radzieckim, Toruń 2002.

Dawid A., Lusek J. (red.), Kobiety na Kresach Wschodnich na przełomie XIX i XX wieku, Warszawa-Bellerive-sur-Allier-Bytom-Opole 2016.

Duraczyński E. (red.), Układ Sikorski-Majski. Wybór dokumentów, Warszawa 1990.

Głowacki A., Sowieci wobec Polaków na ziemiach wschodnich II Rzeczypospolitej 1939-1941, Łódź 1997.

Gnatowski M., W radzieckich okowach. Studium o agresji 17 września 1939 roku $i$ radzieckiej polityce $w$ regionie tomżyńskim $w$ latach 1939-1941, Łomża 1997.

S.M. Grażyna od Wszechpośrednictwa NMP, Wychowanie to dzieło miłości. System pedagogiczny bt. Marceliny Darowskiej, Szymanów 1997.

Gurjanow A., Cztery deportacje, „Karta” 1994, nr 12.

S.M. Jarząbek A., Życie, myśl i dzieło Matki Marceliny Darowskiej wspótzałożycielki Zgromadzenia Sióstr Niepokalanek, Warszawa 1990.

Jasiewicz K., Liczba deportowanych, „Karta” 2001, nr 32.

Katyń. Dokumenty zbrodni. T. 2. Zagłada, marzec - czerwiec 1940, opr. W. Materski, Warszawa 1998.

Kość K., Żywi we wspomnieniach. Doświadczenia śmierci w relacjach polskich zesłańców w ZSRR (w latach 1940-1946), Wrocław 2008.

Kowalski G., Warunki życia codziennego na zesłaniu, „Zesłaniec” 2008, nr 36. 
Lusek J., Poświecenie nie jedno ma imię. Siostra Zofia od Serca Jezusowego (Matylda Ustjanowicz), „Biografistyka Pedagogiczna” 2019, r. 4, nr 1.

Mały Rocznik Statystyczny Polski wrzesień 1939 - czerwiec 1941, Warszawa 1990.

Marszałek A. (red.), Położenie ludności polskiej na terytorium ZSRR $i$ wschodnich ziemiach II Rzeczpospolitej w czasie II wojny światowej, Torun 1990.

Pankiewicz A., Sytuacja polskich zesłańców na Syberii w latach II wojny światowej, „Zesłaniec” 2016, nr 66.

Siemaszko Z.S., W sowieckim osaczeniu 1939-1943, Londyn 1991.

Szubtarska B., Ambasada polska w ZSRR w latach 1941-1943, Warszawa 2005.

Ślusarczyk J., Układ polsko-radziecki z 30.7.1941 r. „Wojskowy Przegląd Historyczny" 1980, z. 3.

Watowa O., Paszportyzacja, „Zeszyty Historyczne” 1972, z. 21.

Werra Z., Działalność duszpasterska w 2. Korpusie Polskich Sił Zbrojnych na Zachodzie gen. Władystawa Andersa 1941-1947, Warszawa 2009. 